\title{
The Social Capital of LSES students: Using Student Stories to Mobilise Student Success
}

\author{
Christie White \\ Executive Director (Student Success and Wellbeing) \\ University of Southern Queensland
}

\begin{abstract}
Social capital has been defined in various ways (Bourdieu, 1997; Coleman, 1998; Putnam, 1995) but generally it is associated with the social networks or connections and social structures that people are engaged with, and, has been attributed to social class and subsequently likelihood of success in education (Dika \& Singh, 2002). Traditional theories of people from low socioeconomic backgrounds (LSES) attest that those cohorts have low levels of social capital (Bourdieu, 1997; 2011). This article challenges this assumption and contributes to the growing body of evidence that LSES students in higher education have well developed social capital (Devlin et al., 2012; Macqueen, 2018). Results of a doctoral study, examining the narratives of LSES students in higher education, demonstrates that the students have well-developed skills in seeking out support and social capital which challenges preconceived assumptions about socioeconomic status and social class (White, 2016). Despite life's challenges LSES students were enabled via their own self-agency (Karimshah et al., 2013) to strive for success in higher education and, "their resourcefulness and their social capital aided their ability to navigate the complex and challenging higher education environment" (White, 2016, p.116). This report will share the stories of LSES students and how they mobilised their social capital in order to increase their likelihood of success at university.
\end{abstract}

\section{Keywords}

University, students, low socioeconomic, social capital, student success, social class, self-agency

\section{Background}

Students from low socioeconomic backgrounds (LSES students) come to university with a range of complicating factors that potentially impact on their ability to succeed, for example, financial strain, caring responsibilities, time pressures, and work commitments (Devlin and McKay, 2014; Karimshah et al., 2013; White, 2016). At a time when the Australian higher education sector is being called upon to make greater effort to both widen and broaden participation of students from a range of backgrounds, including LSES students (Australian Government, 2019), it is pertinent to explore the capabilities and strengths that LSES students' bring to the tertiary education environment.

Social capital is a construct that has been attributed to social class and socioeconomic status, as well as success in education by a range of researchers (Bourdieu, 1997; Coleman, 1988; Dika \& Singh, 2002). Sense making of the linkages between social capital and LSES students is possible through listening to the narratives of LSES higher education student experiences.

\section{What is social capital?}

In the academic literature, social capital is defined in multiple ways depending on the recency of the publication or the author. It is a constantly evolving construct and while the definition of social capital is debated in the literature (Bourdieu, 1997; Coleman, 1998; Putnam, 1995, 2000), it is generally associated with the social networks or connections and social structures that people are engaged with, the shared values and understandings that those connections have, and, has also been attributed to social class, as well as success in education (Dika \& Singh, 2002; Putnam, 2000). Social capital is argued to be the relationships that people form with others that enables one to source information, resources or support, or gain access to other forms of capital such as human or cultural capital (Cardak, Bowden \& Bahtsevanoglou, 2015).

Bourdieu is argued to be the first to define social capital in sociological terms (Koniordos, 2008). Bourdieu (1997) describes social capital as the connections and social obligations that individuals 
develop over a lifetime and this capital can transform into other forms of capital such as economic capital. He argues that any deficits in social capital results from the individual's social norms and social networks, including low parental expectations of education and low investment in education. This resulting poor social capital is likely to produce inequality amongst classes, because high levels of social capital is often attributed to the socially powerful middle to upper class (Bourdieu 1997; Sullivan, 2002).

Social capital: LSES and educational outcomes

Bourdieu (1997) argues that LSES students bring low levels of social capital to education. Subsequently, he attributes any underperformance of LSES students in education to diminished social capital (Karimshah et al., 2013). In this sense, Bourdieu argues that LSES students do not have, or are ill-equipped to develop, relationships and networks that enable them to navigate the complexities of education. He and others (Sullivan, 2002; Winkle-Wagner \& McCoy, 2016) attribute the ability to develop social capital to family background and as a result, reinforces the cycle of inequality.

Social capital refers to the attributes and qualities of the family, social and community networks that facilitate cooperation between individuals and communities. The quality of and extent to which individuals are engaged with these networks are likely to impact on the educational and social development of children and youth. It can be argued that network associations and influences can increase educational engagement, achievement and participation over and above the influences of family background, school type and geographical location. (Semo \& Karmel, 2011, p. 7)

In addition to Bourdieu, there are a number of other researchers that attribute positive educational outcomes with high levels of social capital (Coleman, 2988; Dika \& Singh, 2002; Lee \& Oi-Yeung Lam, 2016; Madyun, 2008). Such theorists argue that low levels of social capital result in poor academic performance (Coleman, 1988), impaired transfer of informal knowledge (Madyun, 2008), higher dropout rates and poor educational aspirations (Dika \& Singh, 2002), and reduced cultural capital development (Madyun, 2008).

The research

This presentation is based on a doctoral study that explored LSES student experiences and sought understanding of that experience in order to develop a framework for student support services in higher education that would contribute to positive outcomes for LSES students (White, 2016). More specifically, this article describes the storytelling and constructive analysis of students' own narratives with respect to their help-seeking behaviours and the implications for higher education providers. Analysis of the student narratives challenges the established understandings and preconceived notions of social capital in relation to LSES students. LSES students, in this study, demonstrated high levels of social capital.

\section{Methodology}

In 2016, Grounded Theory Method (GTM) was employed to understand success factors for LSES students in higher education in Australia and to develop a theory that informs institutional student services' planning and service delivery to such cohorts (White, 2016). GTM is a constructivist qualitative research design that provides guidelines for "gathering, synthesizing, analysing, and conceptualizing qualitative data to construct theory" (Charmaz, 2003, p. 82).

Thematic analysis of transcribed data from 17 semi-structured interviews with Australian university students from low socioeconomic backgrounds as well as three university staff members from student-facing roles was undertaken. It is to be recognised that, consistent with a constructivist paradigm, the results of this study were "generated rather than discovered and/or tested" and that the understandings depicted are contextual and give voice to the participants involved (White, 2016, p. 28). There is no presumption of truth-finding or facts but rather the data provides insights into, and 
understanding of, the LSES students' experiences.

For the study LSES students were defined using a definition provided by the Australian Government being those individuals who had home addresses in the lowest quartile of the Socio-Economic Indexes for Areas (SEIFA) Education and Occupation Index (2006), as depicted by the Australia Bureau of Statistics, in combination with those who met relevant income support payment criteria (Department of Education, Employment and Workplace Relations, 2010). Participants were drawn from 'a convenience sample' where those students who had been scholarship and student loan recipients and were included in databases generated by one higher education provider in Australia. Staff participants were identified by their respective positions and known to the researcher.

During the semi-structured interviews, probing questions were included to facilitate each student's narrative and to harness LSES students' stories on a range of matters such as: how they feel about studying at university; what they might define as success; what problems may arise; and what supports they may access. Staff interviewed were asked similar questions and were asked to respond from their own perspective about their understanding of what LSES students think and do. Some of the participants' comments are quoted in this article however false names are used in order to protect the identities of the persons interviewed.

Transcribed data (the student narratives) were coded line by line according to GTM. Focused coding eventuated as themes started to emerge amongst the data (the students' stories) and eventually achieving a saturation point where no new themes emerged. It is these themes that helped the researcher to understand a range of experiences reported by LSES students in higher education. One such theme was the engagement of social networks and connections to aid in their success.

\section{Results}

LSES student narratives provided useful insights into understanding LSES student experiences in higher education, most specifically around accessing support. Of particular note for this article is the importance of relationships and connections for LSES students and how these students navigate those relationships.

\section{Relationships}

LSES students attribute significant importance to the relationships they have with others as positively contributing to their success whilst studying at university. In fact, students reported that relationship building and having relationships was critical to study success. Codes such as 'having personable contact', 'getting to know the person', 'knowing by name', 'having connectedness', and 'having networks' highlighted the importance of relationships (White, 2016, p. 64).

[T] he first time you go and all be together in a dining hall situation, it's about looking for possibly people exactly the same age as you, I suppose. You kind of try and mix with people who possibly have just come from school, or are recently from school, so you've got some similarities there to talk to them first. [Erin, student]

LSES students tended to utilise or build social networks and connections in order to seek answers or to support demonstrating a heightened sense of how to access support. The LSES student participants spoke freely about their experiences of connectedness. 'Having connectedness' was seen as critical in their learning journey as described by a student studying to be a teacher:

It's good to know who - or the lecturer that is there with you, trying to teach you your profession, or whatever course you may be doing. They actually take the effort to reach you on a personal note. I think to have a relationship, whether it's my students or anyone, I think that's fundamental of any good teacher really. That relationship word, so that's the backbone of it I believe. [Jamie, student] 
LSES students developed their networks through links with pre-existing relationships or drew on their life experiences to support them while forging new connections.

...we've all had at least 12 years of schooling that has programmed, you will go to your teacher if you have a problem. [Jessie, student].

The attributes of 'having connectedness', or networks, as described by students is outlined in Figure 1 demonstrating that LSES students in this study had a well-developed understanding of the successful elements of social networks - who benefits from those connections, and what to do with those connections. The networks LSES students established were the mechanisms by which they accessed support at university (White, 2016, p. 74).

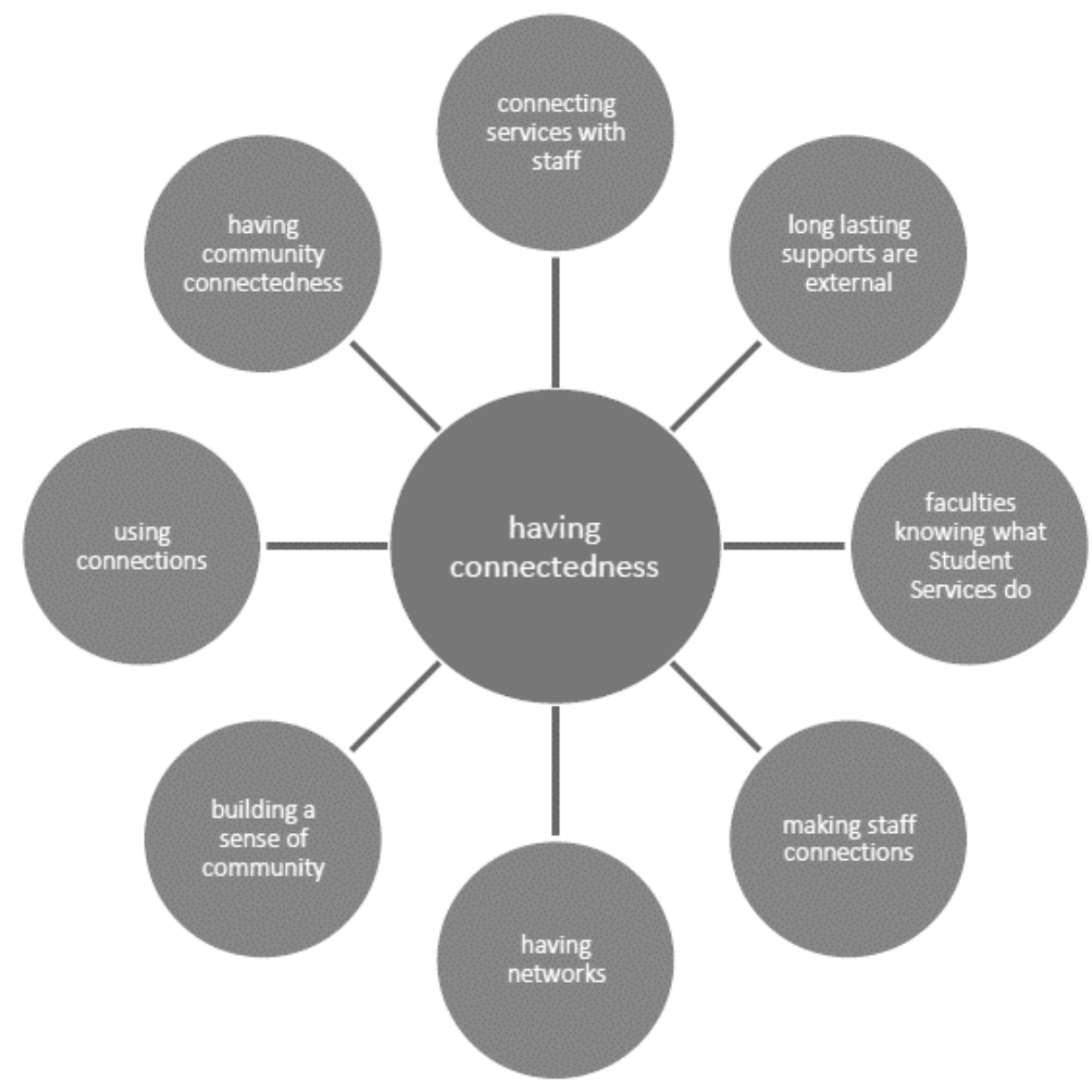

Figure 1: Attributes of 'having connectedness' as described by LSES students (White, 2016, p. 75)

\section{Networks and access to student support}

LSES students tended to seek support in the first instance from the people closest to them. The understanding of their 'supporters' was drawn from codes such as 'having support from your family', 'linking with peers', 'having family who have been there', 'having peers as support', 'learning from peers', 'knowing your peers' , 'using staff as support', 'staff holding my hand', 'staff knowing me', 'seeing academics as most significant other', 'having informed academics', 'having sister as support', and 'asking tutors and lecturers for help'. An example of a LSES student speaking of their supporters is provided below: 
I think it was actually a phone call from my mother actually, saying, you know, you should actually look in and see if you can get a bit of support. I think by memory, that may have been what prompted me to actually look into it further. [Jamie, student]

LSES students' utilised a network of support, primarily from family, their peers, university administration staff, or their lecturers/tutors as highlighted in Figure 2. Critical to the success of accessing support is that their support networks were available ("there", reliable, open, welcoming, show they care), familiar (previous exposure, comfortable, pre-existing), and credible (experience, integrity, expertise) (White, 2016, p. 87). Ultimately, LSES students deemed that those who were considered trustworthy were considered a part of their network to access for support, the 'theory of trusting networks' which can be explored further in White, 2016.

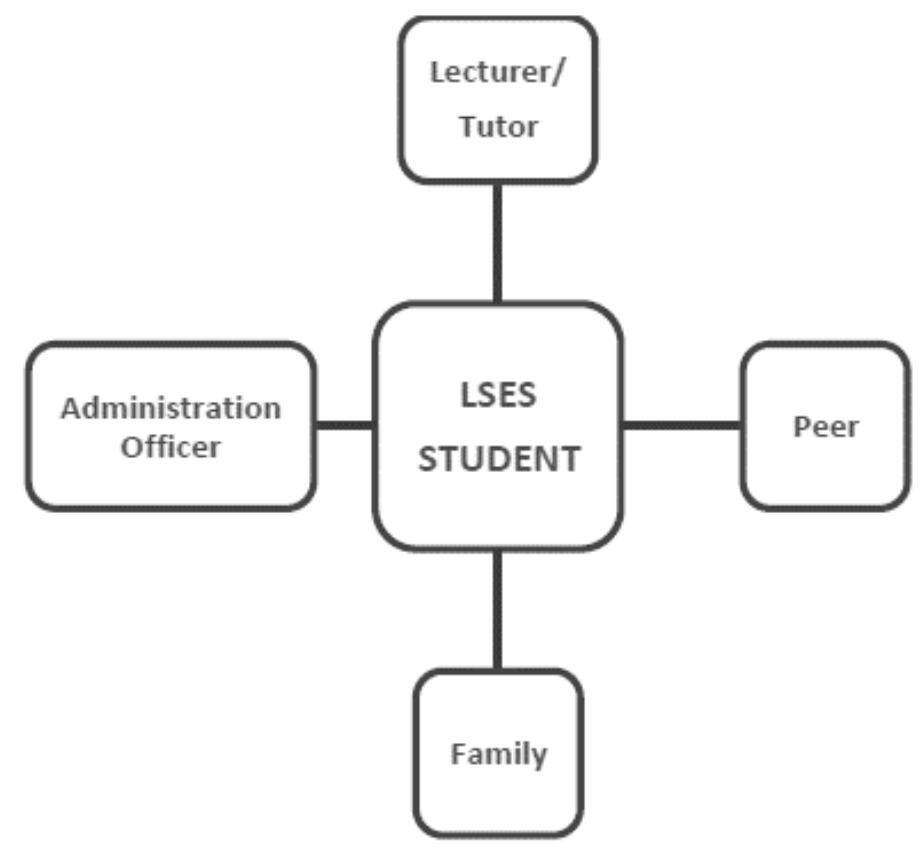

Figure 2: LSES student support network (White, 2016, p. 74)

\section{Discussion}

\section{Interpretation of results}

The research shared offers an understanding of LSES student experiences and demonstrates that the students interviewed deliberately and selectively engaged a social network to access support during their university studies. These networks were primarily family, peers, university administration staff, and/or lecturers/tutors.

LSES students rarely indicated that university specialised student services was a part of their trusted networks. Student services were often mentioned as a secondary support service often referred to by their primary networks. This feeds into the notion that student support services need to have multiple access points and to offer various referral pathways to facilitate access into their service. It is critical to equip those referrers with sufficient information and resources to appropriately direct students. Student support services benefit from establishing ways to demonstrate to LSES students their availability, familiarity and/or credibility and to work toward being considered as a trusted part of a LSES students' network. 


\section{LSES students and their social capital}

While LSES students shared a range of complicating factors that impacted on their student experience, they had well-developed skills in seeking out support that demonstrated high levels of social capital. The sample of students interviewed in this study are likely to have high levels of motivation and resilience given they have achieved success through succeeding to enter higher education. The reported behaviour in this study challenges previous assumptions about LSES students in higher education and their social capital. As per the findings of the original research, "[t]he findings of [this] study challenge components of Bourdieu's [1997 and others'] theor[ies] of social capital that in relation to relevance for the 21 st century higher education context contends that LSES students have differential levels of social capital compared to those of non-LSES students" (White, 2016, p. 115). The way in which LSES students utilise their social networks and relationships is not consistent with the proposition that LSES students have lower levels of social capital. In fact, the finding is quite the contrary. Seeking advice and information from others and utilising existing networks to navigate to desired support is in competition with existing definitions of social capital as described earlier. Are LSES students more accustomed to activating their self-agency in order to achieve positive outcomes? For instance, consider the government and non-government policies, procedures and departments that they may have to navigate in order to access financial or housing assistance. LSES students have demonstrated their self-agency through their personal commitment and a determination towards achieving a set outcome (Karimshah et al., 2013) being in this context, seeking positive outcomes at university.

The connection of LSES students with high levels of social capital is not a new proposition (e.g. Macqueen, 2018). In support of this finding, Devlin et al., (2012) found that 45\% of LSES students identifying that asking for help was an important factor in influencing their success in higher education. Another study in 2015 found that LSES students were more active in their help seeking behaviours than their higher socioeconomic peers who were "more accustomed to having assistance and resources handed to them (McKay \& Devlin, 2015, p. 12). Similarly, another study identified that LSES students, with more experience in higher education, were less influenced by their family background and developed their social capital through the educational institution (Winkle-Wagner \& McCoy, 2016). And further, another study showed that students from educationally disadvantaged backgrounds who had well developed supports, had higher chances of success (Semo \& Karmel, 2011).

It is posited that blanket assumptions about LSES students are not warranted given the heterogeneity of the LSES cohort and the fact that as individuals they demonstrated different experiences and backgrounds in their lifetimes. This research and the known heterogeneity of the LSES student population further challenges previous theories suggesting that socioeconomic status is directly linked to levels of social capital. "For the LSES students in [this] study, their resourcefulness and their social capital aided their ability to navigate the complex and challenging higher education environment" (White, 2016, p. 119).

This study analysed LSES student narratives about their higher education experiences and provides an understanding that updates and challenges previously posited assumptions about the role of socioeconomic status and social capital. It is this student voice that opens potential to identify an approach for student support services to facilitate greater access by LSES students, thereby contributing to their opportunities for student success. 


\section{References}

Australian Government. (2019). Access and participation. Retrieved from https://www.education.gov.au/access-andparticipation

Bourdieu, P. (1997). The forms of capital. In A. H. Halsey, H. Lauder, P. Brown, \& A. Stuart Wells (Eds.), Education: Culture, economy, and society (pp. 46-58). Oxford, England: Oxford University Press.

Bourdieu, P. (2011). The forms of capital (1986). In I. Szeman \& T. Kaposy (Eds.), Cultural theory: An anthology (pp. 81-93). Chichester, England: Wiley-Blackwell.

Cardak, B., Bowden, M., \& Bahtsevanoglou, J. (2015). Are low SES students disadvantaged in the university application process? Perth, WA: National Centre for Student Equity in Higher Education, Curtin University. Retrieved from https://www.ncsehe.edu.au/publications/are-low-ses-students-disadvantaged-in-the-university-applicationprocess/

Charmaz, K. (2003). Grounded theory. In J. A. Smith (Ed.), Qualitative psychology: A practical guide to research methods (pp. 81-110). London, England: Sage Publications.

Coleman, J. S. (1988). Social capital in the creation of human capital. The American Journal of Sociology, 94, 95-120. Retrieved from http://www.jstor.org/stable/2780243

Department of Education, Employment and Workplace Relations. (2010). Higher education participation and partnerships program. Retrieved from http://www.deewr.gov.au/HigherEducation/ Programs/Equity/Pages/HEPPProgram.aspx

Devlin, M., \& McKay, J. (2014). Reframing 'the problem': Students from low socio-economic status backgrounds transitioning to university. In H. Brook, D. Fergie, M. Maeorg, \& D. Michell (Eds.), Universities in transition: Foregrounding social contexts of knowledge in the first year experience (pp. 97-125). Adelaide, SA: University of Adelaide Press.

Devlin, M., Kift, S., Nelson, K., Smith, L., \& McKay, J. (2012). Effective teaching and support of students from low socioeconomic status backgrounds: Resources for Australian higher education. Final Report 2012. Sydney, NSW: Australian Learning \& Teaching Council.

Dika, S. L., \& Singh, K. (2002). Applications of social capital in educational literature: A critical synthesis. Review of Educational Research, 72, 31-60.

Karimshah, A., Wyder, M., Henman, P., Tay, D., Capelin, E., \& Short, P. (2013). Overcoming adversity among low SES students. Australian Universities' Review, 55(2), 5-14.

Koniordos, S. M. (2008). Social capital contested. International Review of Sociology, 18(2), 317-337.

Lee, M., \& Oi-Yeung Lam, B. (2016). The academic achievement of socioeconomically disadvantaged immigrant adolescents: A social capital perspective. International Review of Sociology, 1-30. doi:10.1080/03906701.2016.1112528

Macqueen, S. (2018). Family and social capital for the success of non-traditional students in higher education. International Studies in Widening Participation, 55(1), 37-50.

Madyun, N. (2008). Linking universal instructional design and cultural capital: Improving African American college outcomes. In J. L. Higbee \& E. Goff (Eds.), Pedagogy and Student Services for institutional transformation: Implementing universal design in higher education (pp. 49-58). Minneapolis, MN: The Center for Research on Developmental Education and Urban Literacy, University of Minnesota.

McKay, J., \& Devlin, M. (2015). 'Low income doesn't mean stupid and destined for failure': Challenging the deficit discourse around students from low SES backgrounds in higher education. International Journal of Inclusive Education, 1-17. doi:10.1080/13603116.2015.1079273

Putnam, R. D. (1995). Bowling alone: America's declining social capital. Journal of Democracy, 6(1), 65-78. Retrieved from http://muse.jhu.edu.ezproxy.usq.edu.au/journals/journal_of_democracy/v006/6.1putnam.html

Putnam, R. D. (2000). Bowling alone: The collapse and revival of American community. New York: Simon \& Schuster.

Semo, R., \& Karmel, T. (2011). Social capital and youth transitions: Do young people's networks improve their participation in education and training? Occasional Paper. Adelaide, SA: National Centre for Vocational Education Research. 
Sullivan, A. (2002). Bourdieu and education: How useful is Bourdieu's theory for researchers? Netherlands Journal of Social Sciences, 38(2), 144-166.

Tinto, V. (2007). Access without support is not opportunity. Paper presented at the Centre for the Study of Students, University of Toronto, Toronto, CA.

Tinto, V. (2008, November). Access without support is not opportunity. Paper presented at the 36th Annual Institute for Chief Academic Officers Conference, The Council of Independent Colleges, Seattle, WA.

White, C. (2016). The widening participation agenda in higher education in Australia: theorizing a model of service delivery for non-academic Student Services to support university students from low socioeconomic backgrounds. Accessible from: https://eprints.usq.edu.au/31377/

Winkle-Wagner, R., \& McCoy, D. L. (2016). Entering the (postgraduate) field: Underrepresented students' acquisition of cultural and social capital in graduate school preparation programs. The Journal of Higher Education, 87(2), 178-205.

The author may be contacted:

christie.white@usq.edu.au

Please cite this paper as:

White, C. (2019). The social capital of LSES students: Using student stories to mobilise student success. Journal of the Australian and New Zealand Student Services Association, 27(2), 216-223. https://doi.org.10.30688/janzssa.2019.10 